\title{
Szelektív adszorpció molekuláris lenyomatú polimereken
}

\author{
DORKÓ Zsanett, ${ }^{\mathrm{a}, \mathrm{b}}$ SZAKOLCZAI Anett ${ }^{\mathrm{a}}$ és HORVAI György ${ }^{\mathrm{a}, \mathrm{b},{ }^{*}}$ \\ ${ }^{a}$ BME Szervetlen és Analitikai Kémia Tanszék, Szent Gellért tér 4., 1111 Budapest, Magyarország \\ ${ }^{b}$ MTA-BME Müszaki Analitikai Kémiai Kutatócsoport, Szent Gellért tér 4., 1111 Budapest, Magyarország
}

\section{Bevezetés}

\subsection{Molekuláris lenyomatú polimerek}

A molekuláris lenyomatú polimer (molecularly imprinted polymer; MIP) olyan mesterségesen elöállított adszorbens, amely esetenként - a szakirodalomban elfogadott nézetek szerint ${ }^{1,2}$ - a természetes antitest-antigén kölcsönhatással összemérhető kötéserősséggel és szelektivitással képes felismerni és megkötni egy kiválasztott molekulát. A természetes, ellenanyag alapú adszorbensekkel összehasonlítva a MIP-ek előnye, hogy előállításuk jóval olcsóbb és szélsőséges körülmények között is stabilak.

$\mathrm{Az}$ ú.n. nemkovalens MIP-ek készítésekor (1. ábra) a polimerizáció során a monomereken kívül jelen van egy templát - ez általában a későbbi célvegyület. Miután a polimerizáció végbement, a templátot eltávolítjuk a rendszerből, azonban az őt körülvevő monomerek helyzete a polimer keresztkötéseinek köszönhetően nem változik. Ezáltal olyan, kémiai- és alak-specifitással rendelkező kötőhelyek maradnak vissza, ahová a célvegyület később be tud épülni, de más vegyületek kötődése várhatóan gyenge lesz. Az így készült szelektív adszorbenseket nevezzük MIP-eknek. A MIP-ek szelektivitása jól kihasználható különböző analitikai és elválasztástechnikai alkalmazásokban, például kromatográfiában vagy szenzorokban. ${ }^{3-5}$

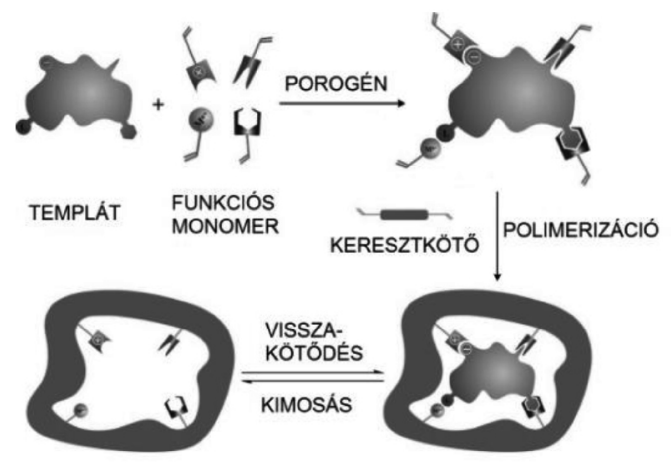

1. Ábra A molekuláris lenyomatképzés elve

A MIP-ek előállítására használt polimerizációs elegy összetevői általában a következők:

- Templát (célvegyület vagy annak szerkezeti analógja)

- Funkciós monomer: amely tartalmaz olyan funkciós csoporto(ka)t, mely(ek) képes(ek) a templát molekulával első-, vagy másodrendü kötést létesíteni; továbbá tartalmaz polimerizációra képes kettős kötést
- Keresztkötő: több kettős kötése van, így térhálós polimer kialakítását teszi lehetővé, rögzíti a funkciós monomerek helyzetét

- Porogén: a polimerizációs elegy „inert” oldószere, amely a pórusok kialakításáért is felelős

- Iniciátor: a polimerizációs reakció elindítója.

Általában a MIP-ek mellett NIP-eket (nem imprintelt polimer, kontrol polimer) is szintetizálunk, amelyek templát hozzáadása nélkül, a MIP-ekhez hasonlóan készülnek. A MIP és a NIP adszorpciós tulajdonságainak összehasonlításával képet kaphatunk arról, hogy hogyan változik meg a polimer tulajdonsága a lenyomatképzés (imprintelés) hatására.

\subsection{Molekuláris lenyomatú polimerek jellemzésének nehézségei}

A MIP-ek szelektivitása számos technikában kihasználható, mint például kromatográfiában, szenzorokban, mintaelőkészítés (szilárdfázisú extrakció, SPE) során. Kereskedelmi forgalmazásban azonban szinte csak SPE töltetként, illetve egyes ipari problémák megoldására elérhetők. A MIP-ek elterjedését gátolja az, hogy a kötőhelyek szerkezetének közvetlen vizsgálata eddig még nem sikerült. A MIP-ek vizsgálatának eddig bevált módszerei pedig nem egységesek: a MIP-ek jellemzése (kötőkapacitás, szelektivitás) az irodalomban sokféle módon történik, és a kapott eredmények összevethetősége bonyolult lehet. A kromatográfiában a $k$ retenciós tényezőt, szilárdfázisú extrakcióban a visszanyerés értékét, ligandum kötési assayekben az IC50 értéket használják a polimerek jellemzésére, ezek egymással való összehasonlítása azonban nehézkes (nem egyensúlyi értékek valamint nagyon függenek az alkalmazott kísérleti körülményektől). Így nehéz összehasonlítani a különböző laboratóriumokban elkészített polimerek tulajdonságait és kiválasztani a legalkalmasabb polimert egy adott analitikai feladatra.

\section{Célkitűzés}

Munkánk során célunk volt a nemkovalens kölcsönhatáson alapuló molekuláris lenyomatú polimerek olyan alapvető tulajdonságainak átfogó jellemzése, mint a szelektivitás vagy kötőkapacitás. Ezen vizsgálatokhoz a már széles körben tanulmányozott propranolol MIP-et választottuk. ${ }^{6} \mathrm{~A}$ vizsgált polimerek metakrilsav és etilén-glikol-dimetakrilát alapúak voltak.

*Tel.: +36-1-4631480 ; fax: +36-1-4633408 ; e-mail: george.horvai@mail.bme.hu 
Mivel a gyakorlati szempontból releváns célvegyületek nagy része gyenge bázis (pl. triazinok, beta-blokkolók), ezért a beta-blokkoló propranolol és más bázisok adszorpciójának mechanizmusát és mértékét különböző összetételü és előállításmódú, metakrilsav alapú polimereken vizsgáltuk. Célunk volt meghatározni a polimerek kötőkapacitását, illetve azt, hogy mely tényezők befolyásolják a polimerhez kötődést.

\section{Eredmények}

\subsection{Polimerek kötőkapacitásának vizsgálata ${ }^{7}$}

A MIP-ek a célvegyületeket a kötöhelyeiken kötik, amelyek általában valamilyen funkciós csoportot (legtöbbször karboxilcsoportot) tartalmaznak. A polimerbe beépült karboxilcsoportok mennyiségét és ezek elérhetőségét azonban nem szokták meghatározni.

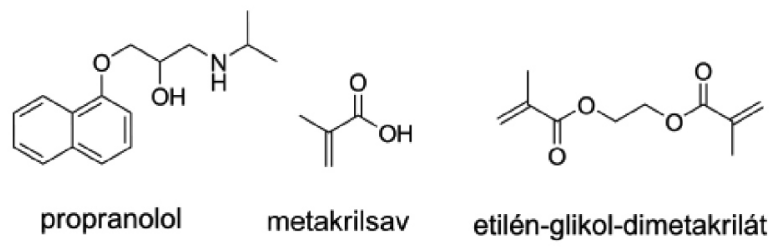

2. Ábra. A templát és a monomerek szerkezete

Kísérleteinkben megmutattuk, hogy szinte valamennyi karboxilcsoport beépül a polimerbe és elreagáltatható az erős bázis $\mathrm{NaOH}$-dal. Propranololból, tehát egy közepesen gyenge bázisból, a MIP viszont csak a karboxilcsoportok kb. $30 \%$-ának megfelelő mennyiséget tud megkötni. A NaOH és a propranolol kötődése közötti különbség legfőbb oka az eltérő mértékü báziserősség lehet.

További, más bázisokkal és polimerizációs receptúrákkal végzett kísérletekből valóban arra a következtetésre jutottunk, hogy a polimer összes karboxilcsoportja felhasználható szerves bázisok adszorpciójára, ha a bázis elég erős (például: 1,8-diazabiciklo[5.4.0]undek-7-én) és ha a polimer elég rugalmas (pl. dimetil-formamidban készült polimer). Ez az eredmény új a MIP-ekkel kapcsolatban, mert eddig úgy gondolták, hogy a bevitt funkciós csoportok mennyiségénél lényegesen kevesebb a szerves bázisok megkötésére alkalmas kötőhelyek mennyisége. Ez az elképzelés részben a nem megfelelő mérési módszeren alapult. Az irodalomban például egy az általunk vizsgálthoz hasonló propranolol MIP-re a kötőhelykoncentrációt a propranolol izoterma kis koncentrációkhoz tartozó szakasza alapján csupán a karboxilcsoportok 4\%-ára becsülték ${ }^{6}$ szemben az általunk kapott kb. 30 \%-kal. Ez azt jelzi, hogy a kötőkapacitást mindig közvetlenül, azaz nagy koncentrációknál végzett méréssel érdemes meghatározni.

\subsection{Izoterma modellek összehasonlítása ${ }^{8}$}

Úgy gondoljuk, hogy a MIP-ek jellemzésének legegyértelmübb módszere az adszorpciós izoterma felvétele. $\mathrm{Az}$ izoterma az egyensúlyi adszorbeált koncentrációt $(q)$ mutatja a szilárd határfelületi fázisban, az oldatbeli koncentráció (c) függvényében. A MIP-ek adszorpciós izotermája nemlineáris. Az izoterma mérési pontokra sokszor valamilyen modell-függvényt illesztenek. Többen tapasztalták, hogy ugyanahhoz az izoterma adatsorhoz többféle modellt is lehet hasonló sikerrel illeszteni. ${ }^{9,10}$ Ez komoly probléma, ha a modell paramétereit a kötőhelyek eloszlásának és a kötés erősségének a jellemzésére, és ezen keresztül az adszorbensek fejlesztésére akarják használni.

Munkánk során azt vizsgáltuk, hogy a bi-Langmuir-modell mennyire jól tudja közelíteni a Freundlich-modellt, ezen izoterma egyenletek ugyanis MIP-eknél gyakran adnak hasonlóan jó illeszkedést a mérési pontokhoz. A bi-Langmuir modell írja le a lenyomatképzés jelenleg leginkább elfogadott elméletét, mely szerint a lenyomatképzés során kétféle kötőhely jön létre: az egyik a kis koncentrációjú erős és a templátra szelektív kötőhely, a másik pedig a nagy koncentrációjú gyenge és nem szelektív kötőhely. A Freundlich-izoterma:

$$
q=a \mathrm{c}^{m}
$$

ahol $a$ és $m(0<m<1)$ konstans.

A bi-Langmuir-izoterma:

$$
q=\left(a_{1} /\left(1+b_{1} c\right)\right)+\left(a_{2} /\left(1+b_{2} c\right)\right)
$$

ahol $a_{1}, a_{2}, b_{1}$ és $b_{2}$ konstansok.

Azt tapasztaltuk, hogy amennyiben egy rendszer viselkedése jól leírható a Freundlich-izotermával, a legtöbb esetben a bi-Langmuir-modell is hasonlóan jó illeszkedést ad. Ezt Monte Carlo-szimulációval, illetve a matematikai függvények összehasonlításával mutattuk be. A 3. ábra mutatja a Freundlich-modell $\left(q=1000 c^{m}\right)$ és a hozzá legjobban illeszkedő bi-Langmuir-modell relatív eltérését a $\lg c$ függvényében.

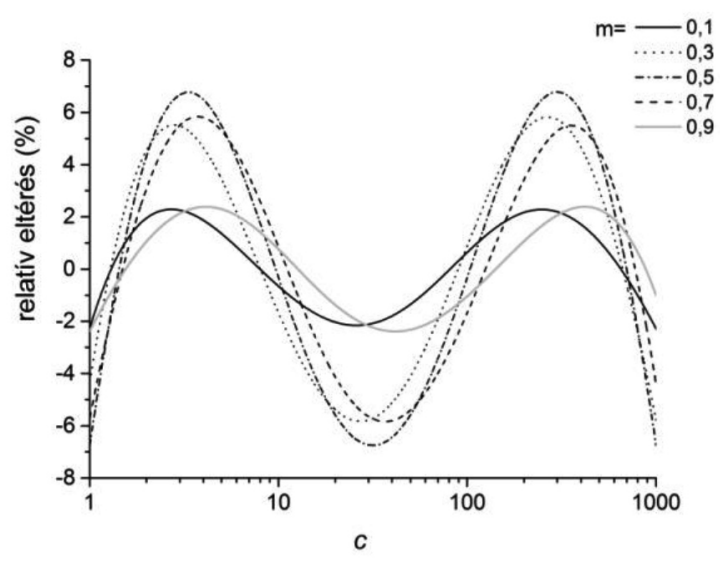

3. Ábra. Freundlich- $(a=1000)$ és bi-Langmuir-izoterma közötti eltérés különböző $m$-ek esetében

Ahogyan a 3. ábra mutatja, minden Freundlich-izoterma (ahol $a=1000$, de ugyanez adódik más $a$ értékekre is) maximum 7\%-os eltéréssel megközelíthető egy bi-Langmuir-izotermával. A tipikus statikus (batch) mérések szórása 5\% körüli. Ez azt jelenti, hogy amennyiben a mért adatok jól leírhatóak a Freundlich-izotermával, szinte lehetetlen a bi-Langmuir-modellt kizárni akkor is, ha a vizsgált koncentrációtartomány viszonylag széles. 
Ebből az eredményből kiindulva felvetődik a kérdés, hogy érdemes-e a polimereket különböző adszorpciós modellegyenletekkel jellemezni.

\section{3. Újszerü izoterma ábrázolási módszer ${ }^{11}$}

Véleményünk szerint a polimer jellemzés legjobb módszere az izotermák felvétele, azonban az előző fejezetben bemutatott problémák miatt konkrét izoterma egyenletek illesztését a mérési pontokhoz nem javasoljuk.

A problémák kiküszöbölésére egy újszerü módszerrel, kétszer logaritmikus grafikus ábrázolásmódban hasonlítottuk össze az általunk mért adszorpciós izotermákat. Ennek segítségével olyan diagramokat kaptunk, ahol a pontok széles koncentrációtartományban közel egy egyenesre illeszkednek, azonban trendvonal illesztése nélkül is következtetéseket lehet levonni például a szelektivitásra vonatkozólag. Ezzel a módszerrel vizsgáltuk meg számos saját készítésü és kereskedelmi polimer adszorpciós viselkedését. A módszer fó elönye, hogy közvetlenül leolvashatóak az ábráról a polimert jellemző paraméterek, mint a megoszlási hányados $(D=q / c), \mathrm{az}$ imprinting faktor $\left(I F=D_{\mathrm{MIP}} / D_{\mathrm{NIP}}\right)$ és a szelektivitás $\left(\right.$ Szel $\left.=D_{\text {templát }} D_{\text {analóg vegyület }}\right)$, (valamint ezek koncentrációfüggése, amit sokan helytelenül nem vesznek figyelembe), ahogy a 4. ábra mutatja.
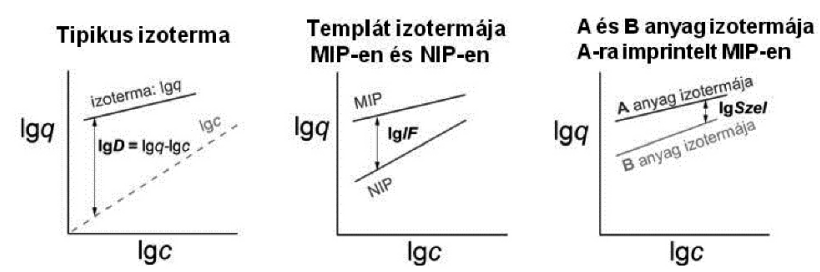

4. Ábra. A megoszlási hányados $(D)$, az imprinting faktor $(I F)$ és a szelektivitás $(S z e l)$ leolvasása a $\lg q$ - $\lg c$ ábráról

Az izotermák lg-lg ábrán való összehasonlításakor elegendő:

- az izotermát a számunkra érdekes koncentrációtartományban megmérni

- logaritmikus egységenként 2-3 pontot felvenni

- a méréseknek nem kell nagyon precíznek lenniük.

Ez a fajta ábrázolásmód grafikus úton egyszerüen összehasonlíthatóvá teszi a különböző laboratóriumokban készített polimereket, ezáltal könnyen kiválasztható az irodalomból is a megfelelö polimer egy adott feladatra.

Munkánk során a propranolol MIP szelektivitását vizsgáltuk részletesen ezzel a módszerrel: a propranolol és két szekunder amin ((R)-(-)-2-benzilamino-1-feniletanol (Rbz) és dibenzil-amin (DBA)) izotermáját mértük meg a propranolol MIP-en a porogénben, acetonitrilben (ACN), ld. az 5. ábrát.

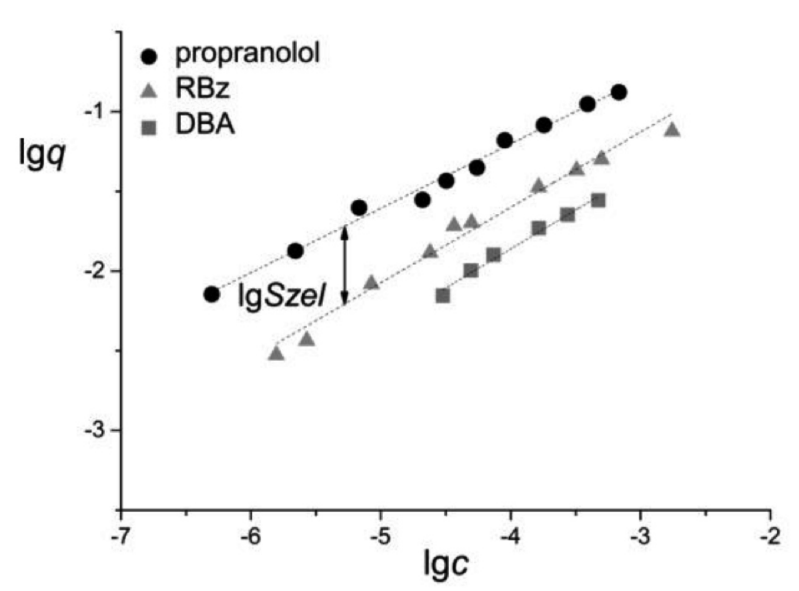

5. Ábra. Propranolol MIP szelektivitása

Eredményül azt kaptuk, hogy érdekes módon az aminok izotermája a propranolol MIP-en közel párhuzamos egymással. Ez azt jelenti, hogy a propranolol MIP szelektivitása szinte nem változik a koncentrációval. A propranolol MIP szelektivitása minden koncentrációnál kisebb 10-nél (mivel az 5. ábrán lgSzel<1). Azonban a MIP szelektivitása szerkezetileg távoli, nem középerős bázis típusú anyagokkal szemben sokkal nagyobb 10-nél (csoportszelektivitás), ahogyan ez várható is, ld. a 6. ábrát.

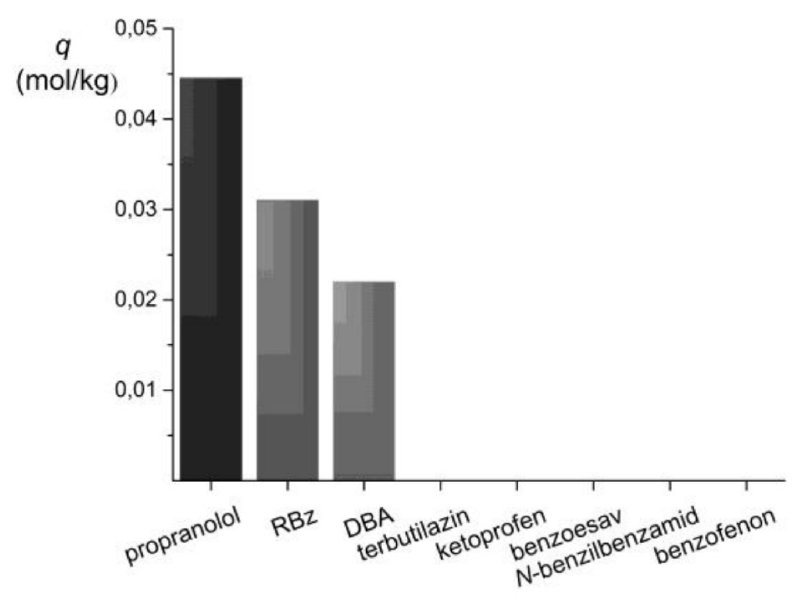

6. Ábra. Propranolol MIP szelektivitása propranololtól szerkezetileg nagyon különböző anyagokra (összehasonlításul két szekunder amint, RBz-t illetve DBA-t is bemutatva) ACN-ben

A MIP izotermák nyújtotta információk segíthetnek kiválasztani a megfelelő alkalmazást. A kromatográfia a hasonló vegyületek közt tapasztalt (5. ábra) kis szelektivitás esetén is alkalmas az anyagok elválasztására. Mivel az SPE sokkal kevésbé hatékony a HPLC-hez képest, az SPE alkalmazásokban leginkább a MIP nagy csoportszelektivitását használják ki (v.ö. 6. ábra). 
Az újfajta ábrázolásmóddal többféle MIP-et és NIP-et vizsgáltunk és számos új, az eddigi szemlélettel részben ellentétes eredményre jutottunk. Érdekes módon a NIP szelektívebb a propranololra a különböző szekunder aminokkal szemben, mint a propranolol MIP (A MIP-en megnő valamennyi amin kötődése a NIP-en mérthez képest, a két polimeren azonos a vizsgált vegyületek szelektivitási sorrendje. Mivel a MIP-en kisebb a kötődésbeli különbség az anyagok között mint a NIP-en, ezért azt mondhatjuk, hogy a NIP szelektívebb a propranololra, mint a propranolol MIP). A vizsgált esetekben az imprintelésért leginkább az amino csoport felelős, az amin templátok pontos szerkezetének, alakjának alárendelt szerepe van (ld. 5. és 6. ábra). Így bizonyos esetekben a célvegyülettől eltérő molekulával imprintelt, vagy nem imprintelt polimerek is a célvegyülettel imprintelt polimerhez hasonló előnyökkel rendelkezhetnek.

\subsection{Kompetitív izoterma megadása ${ }^{12}$}

A MIP-ek alkalmazásaiban gyakori feladat egy anyag egy (vagy több) zavaró anyagtól való elválasztása. Ezért a keverék izoterma (amikor legalább két adszorbeálódni képes anyag van együtt az oldatban a polimer mellett) felvétele közelebb áll sok valóságos alkalmazáshoz, mint a tiszta oldatoké. Az együtt jelenlévő anyagok többnyire csökkentik egymás kötődését, ezért a kevert oldatos izotermákat kompetitív izotermáknak hívjuk.

Kompetíciós (két bázis elegyével történő) méréseket végezve a propranolol MIP-en, arra jutottunk, hogy a bázisok megoszlási hányadosa független attól, hogy kevert vagy külön oldattal érünk el egy adott borítottságot a polimeren. Ez azt jelenti, hogy a két tiszta anyag izotermája ebben az esetben meghatározza az elegy izotermát. Ez az eredmény jelentősen lecsökkenti a szükséges mérések számát, valamint egyszerüen megtervezhetővé teszi a MIP-es elválasztási feladatokat.

\section{Kísérleti módszerek}

A propranolol MIP-et irodalmi leírás alapján készítettük. ${ }^{6}$ Valamennyi polimer tömbpolimerizációs eljárással készült. A polimerből a templátot $0,01 \mathrm{M}$-os, metanol-vizes sósav oldattal távolítottuk el. A polimerbe nem beépült metakrilsav (MAA) mennyiségét a polimer metanolban történő áztatásával vizsgáltuk. A felülúszó MAA tartalmát HPLC-vel mértük meg. A polimerek kationcserélő kapacitását potenciometrikus titrálással határoztuk meg. Szerves bázisok adszorpciójának vizsgálatakor adott tömegü polimert Eppendorf csövekbe mértünk, majd hozzá pipettáztuk az analát oldatát. Az oldatban maradt (nem megkötött) analát mennyiségét 30 perc inkubálási idő után határoztuk meg a minták felülúszójából HPLC-vel. Az izotermákat a fázisarány és/vagy a kiinduló analát koncentráció változtatásával vettük fel. Az izoterma illesztés a Microsoft Office Solver programjában történt.

\section{5. Összefoglalás}

Munkánk során részletesen vizsgáltuk a molekuláris lenyomatú polimerek gyakorlati szempontból fontos tulajdonságait, mint a kötőkapacitás és a szelektivitás.
A polimerek tulajdonságait nagy kötődési szint ( $q$ érték) mellett sokszor nem vizsgálják meg, csak az alacsonyabb koncentrációknál mért izoterma pontokból következtetnek a maximális kötőképességre. Ez a gyakorlat azonban helytelen, a ténylegesen mért kötőkapacitások ennél az értéknél jóval nagyobbak. A kötőkapacitás vizsgálatakor elért eredményeink hozzájárulhatnak nagy kapacitású polimerek előállításához, illetve a polimerek kötőhelyeinek jobb megértéséhez.

Megmutattuk, hogy félrevezető lehet az izoterma adatpontokhoz modell függvényeket illeszteni. Az izoterma kiértékelési problémák kiküszöbölésére az izotermákat $\lg q-\lg c$ ábrán javasoltuk megjeleníteni. Ezen az ábrán többnyire egyenesek vagy enyhén hajló görbék illeszthetőek a mérési pontokra egy széles koncentrációtartományban, így az izotermák vizuálisan is könnyen összehasonlíthatóak egymással. Ez az új módszer egyszerü és robusztus, és segít kiválasztani a megfelelő polimert egy adott analitikai feladatra. Jól követhető vele az imprintelés hatása, az imprintelt polimerek szelektivitása Megmutattuk, hogy a vizsgált propranolol MIP szelektivitása más gyenge bázisokkal szemben nem túl nagy, a nem imprintelt polimerekéhez hasonló. Nem bázikus vegyületekkel szemben viszont nagy szelektivitást kaptunk.

\section{Köszönetnyilvánítás}

Köszönettel tartozunk a NKFIH-nak (OTKA) (K120075).

\section{Hivatkozások}

1. Lavignac, N.; Allender, C. J.; Brain, K. R. Anal. Chim. Acta 2004, 510, 139-145.

https://doi.org/10.1016/j.aca.2003.12.066

2. Andersson, L. I., Muller, R., Vlatakis, G., Mosbach, K., Proc. Natl. Acad. Sci. 1995, 92, 4788-4792. https://doi.org/10.1073/pnas.92.11.4788

3. Molecularly Imprinted Polymers. Man-Made Mimics of Antibodies and Their Application in Analytical Chemistry; Techniques and Instrumentation in Analytical Chemistry, Sellergren, B. Ed.; Elsevier Science: Amsterdam, 2001.

4. Handbook of Molecularly Imprinted Polymers, Alvarez-Lorenzo, C.; Concheiro, A., Eds.; Smithers Rapra, Shrewsbury, 2013.

5. Molecular Imprinting, Haupt, K., Ed.; Springer, Heidelberg, 2013.

6. Andersson, L. I. Anal. Chem., 1996, 68, 111-117. https://doi.org/10.1021/ac950668

7. Dorkó, Z.; Szakolczai, A.; Verbić, T.; Horvai, G. J. Sep. Sci., 2015, 38, 4240-4247.

https://doi.org/10.1002/jssc.201500874

8. Dorkó, Z.; Szakolczai, A.; Tóth, B.; Horvai, G. Period. Polytech-Chem., 2017, 61, 10-14. https://doi.org/10.3311/PPch.10103

9. Sajonz, P.; Kele, M., Zhong, G. M.; Sellergren B.; Guiochon, G. J. Chromatogr. A, 1998, 810, 1-17. https://doi.org/10.1016/S0021-9673(98)00247-7

10. Gritti, F.; Guiochon, G. J. Chromatogr. A, 2007, 1144, 208-220. https://doi.org/10.1016/j.chroma.2007.01.057

11. Dorkó, Z.; Tamás, B.; Horvai, G. Talanta, 2017, 162, 167-173. https://doi.org/10.1016/j.talanta.2016.10.027

12. Dorkó, Z.; Tamás, B.; Horvai, G. Period. Polytech-Chem., 2017, 61, 33-38. https://doi.org/10.3311/PPch.9726 


\section{Selective adsorption on molecularly imprinted polymers}

Molecularly imprinted polymers (MIPs) are selective sorbents. Molecular imprinting involves self-arrangement of polymerizable functional monomers around a template molecule, followed by polymerization and template removal. Therefore, complementary size, shape, and functionalities toward the template in the polymer can be obtained. Consequently, MIPs are expected to rebind the template molecule and possibly also its structurally similar compounds selectively. A control polymer is often made in the absence of the template (NIP: nonimprinted polymer).

MIPs have been used for the development of various analytical and technological methods such as liquid chromatography, capillary electrochromatography, solidphase extraction (SPE), membrane separations, binding assays and sensors. One reason for the slower than expected progress with MIPs may be the use of difficult to compare characterization methods. Our aim was to develop better methods for the determination of the binding capacity and selectivity of molecularly imprinted polymers. Furthermore, a simple graphical tool has been proposed, which allows to select the most suited adsorbent (MIP or other material) for solving an actual practical problem.

MIPs bind their target compounds at binding sites. Despite many efforts, the exact chemical structure of these binding sites could not yet be revealed. The binding sites are typically based on some type of functional groups, like carboxylic groups. The total amount of such functional groups and their distribution into available and unavailable groups is not well known. The total binding capacity is usually indirectly determined by extrapolation from adsorption isotherms, which are measured much below the real binding capacity. Such an indirect measurement published in the literature had found that the binding capacity of a propranolol imprinted polymer was only $4 \%$ of its $\mathrm{COOH}$ content. We have found by direct measurement at high propranolol concentration that a similar polymer binds propranolol equivalent to $30 \%$ of the $\mathrm{COOH}$ groups. This actually measured value still lags behind the capacity for binding the $\mathrm{OH}$ groups of $\mathrm{NaOH}$, which is close to $100 \%$. The difference may be due to the difference in the strength of the two bases. Indeed, we have found that an organic superbase can be bound almost like $\mathrm{NaOH}$.

The most suitable method of MIP characterization is by the use of binding isotherms. These are equilibrium data and thus easily comparable between polymers and adsorptives, independently from the laboratory. Typically some model equation is fitted to the measured isotherm data, and the parameters of the model are further used. We have shown that given the imprecision of isotherm data, neither the selection of the isotherm type, nor the physical interpretation of the obtained constants is on a safe ground. Our suggested method for isotherm presentation $(\log q-\log c$ plot $)$ is a simple method for MIP testing, and the precision of the measured data is also less critical than in equation fitting. Important properties of polymers can be read from these log-log plots, like the logarithm of the imprinting factor $(I F)$, the selectivity $(\mathrm{Sel})$ and the distribution ratio $(D)$. The $\log q-\log c$ graphs show very transparently the selectivity of the polymers. It has been shown for example, that the selectivity of the propranolol MIP is low against other organic bases of comparable base strength, but excellent against many other compounds. It has also been found that under specific conditions NIPs may have interesting practical properties, not much different from the MIP.

Based on our results with competitive isotherms, batch separation experiments can be easily designed and the selectivity of the MIPs is also easily determined without the tedious measurement of the full competitive isotherm. 